me in early 1959 when the levels in vivo were increasing, and a value of about 2 for the dietary discrimination factor was estimated by Langham and Anderson ${ }^{22}$.

I am indebted to Mr. R. G. Speight for assistanco in many of the measurements reported.

Note added in proof. The decrease from March 1960 of the mean crsium-137/potassium ratio in vivo has been maintained. In September the value for 13 subjects resident in Berkshire and Oxfordshire was

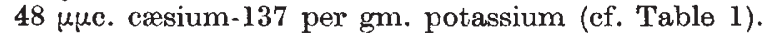

1 Miller, C. E., and Marinelli, L. D., Science, 124, 122 (1956).

${ }^{2}$ Rundo, J., Brit. J. Radiol., Supp. 7, 125 (1957)

s Burch, P. R. J., Bird, P. M., and Spiers, F. W., Brit. J. Radiol., Supp. 7, 128 (1957).

${ }^{4}$ Rundo, J., Atomic Energy Research Establishment Report AERE HP/M 126 (H.M.S.O., 1958).

' Rundo, J., Proc. Second Int. Conf. Peaceful Uses of Atomic Energy, 23, $101^{\prime}(1958)$.

${ }^{6}$ Mayneord, W. V., Anderson, W., Bentley, R. E., Burton, L. K., Crookall, J. 0 and Trott, N. G., Nature, 182, 1473 (1958).

${ }^{7}$ Burch, P. R. J., Nature, 183, 515 (1959).

${ }^{8}$ Booker, D. V., Phys. Med. Biol., \{2, 29 (1957); Nature, 183, 921 (1959).

'Ellis, F. B., Howells, H., Russell, R. S., and Templeton, W. L.,
${ }^{10}$ Spiers, F. W., Appendix J, "The Hazards to Man of Nuclear and Allied Radiations". Cmnd. 9780 (H.M.S.O., 1956).

${ }^{11}$ MeNair, A., Glover, R. N., and Wilson, H. W., Phil. Mag., 1, 199 (1956).

12 Backenstoss, G., and Goebel, K., Z. Naturforsch., 10, $a, 920$ (1955).

${ }^{13}$ Bush, F., Brit. J. Radiol., 19, 14 (1956).

${ }_{14}$ Mayneord, W. V., Brit. J. Radiol., Supp. 2, 154 (1950).

${ }^{15}$ Loevinger, R., Phys. Med. Biol., 1, 330 (1957).

${ }_{16}$ Wasserman, R. H., Twardock, A. R., and Comar, C. L., Science, 129, $568(1959)$.

${ }_{17}$ Miller, C. E., and Marinelli, L. D., Argonne National Laboratory Report $A N L-5919,74$ (1958).

${ }^{18}$ Miller, C. E., Argonne National Laboratory Report $A N L-6104,7 \times$ (1960).

18 Anderson, E. C., Schuch, R. L., Fisher, W. R., and Langham, W. H., Science, 125, 1273 (1957).

${ }^{20}$ Anderson, E. C., Science, 128, 882 (1958).

${ }^{21}$ Anderson, E. C., Clinton, B., and Shields, J. L., Los Alamos Sclentific Laboratory Report $L A-2296$ (1959).

${ }_{22}^{2}$ Langham, W. H., and Anderson, E. C., Health Phys., 2, 30 (1959).

${ }_{23}$ Stewart, N. G., Osmond, R. G. D., Crooks, R. N., Fisher, E. M. R. and Owers, M. S., A tomic Energy Research Establishment Report
and

${ }_{24}$ Crooks, R. N., Osmond, R. G. D., Owers, M. J., and Fisher, E. M. R. Atomic Energy Research Establishment Report $A E R E^{\prime}-R 3094$ (H.M.S. . 1959)

${ }^{25}$ Peirson, D. H., Crooks, R. N., and Fisher, E. M. R., Atomic Energy Peirson, D. H., Crooks, R. N., and Fisher, E. M. R., Atomic Energy

${ }^{26}$ McNeill, K. G., and Green, R. M., Canad. J. Phys., 37, 683 (1959).

${ }^{27}$ Miller, C. E., and Marinelli, L. D., Argonne National Laboratory Report, $A N L-5755,47$ (1957).

\title{
OBITUARIES
}

\section{Prof. H. W. Swift}

Herbert WALKER Swift, emeritus professor of engineering in the University of Sheffield, died near Keswick on October 14. He was borm in 1894. From elementary school he won a scholarship to Christ's Hospital and from there an open scholarship to St. John's College, Cambridge, where he read mathematics and physics. He served in the First World War, rising to the rank of captain, and was wounded and mentioned in despatches. After the War he returnod to Cambridge and completed the Mechanical Science Tripos as a prizeman with first-class honours and ho also won a 'half-blue' for swimming.

Swift obtained his early engineering experience with Hollins Brothers, where he became chief engineer. In 1922 he was appointed assistant lecturer in the University of Leeds. By 1926 he had published papers on several diverse topics and was awarded a D.Sc. by the University of London. For ten yoars he was head of the Mechanical Engineering Department at Bradford Technical College, and continued to publish in the field of power transmission and lubrication.

In 1936 Dr. Swift was appointed to the chair of engineering in the University of Sheffield, which ehair then ombraced the Civil, Mechanical and Electrical Departments of the University. During his period at Sheffield he was induced to take a scientific interest in the plastic forming of metal in all manner of forming processes. At a time of empiricism in this field, he made a remarkable impact in bringing logical and scientific thought to the problems involved and was the instigator of a school of plasticity which has had far-reaching subsequent influence through the work of his students.

$\mathrm{He}$ was responsible for the planning of both buildings and coursos in the enlargement of the School of Engineering at the University of Sheffield. His ill-health brought about his premature retirement just before this task was complete.
Swift was a man of immense energy, deep insight, great enthusiasm and great kindnoss. $\mathrm{He}$ was brilliant, thorough and nevor mediocre. He had an unquenchable thirst for knowledge. In addition, his students will remember him as a vigorous and inspiring teacher with a roadiness to appreciate their personal probloms and treat them sympathotically.

$$
\text { J. P. Duncan }
$$

\section{Dr. H. Zeitlinger}

HennRich ZeitLINGER joined the firm of Henry Sotheran and Co. in 1894; save for a short break, he remained with it until his death on October 15 . in his ninotieth year. A bookseller of distinction, he rendered notable service to scienco.

The volumes of Sothoran's "Bibliotheca ChemicoMathematica" were, according to the original titlepage, "compiled and annotated by $H$. Z [eitlinger] and H. C. S[otheran]", and on them Zoitlinger lavishod tho affection and erudition of the true bibliophile. Almost evory famous work on the exact sciences is listed, with comments identifying and characterizing the author, indicating the content, and illuminating the treatment by apt quotation from a wide varioty of authorities. An austors bibliographer might wish that these quotations had been dated, since this would have helped in tracing changes in critical estimation, but the defoct is slight in such a wealth of scholarship spicod with gontle humour. Where elso, for example, can ono hope to learn of the only mathomatical treatise written to alleviate the pangs of sciatica?

Zeitlinger's expert knowledge of Newton's work onabled him to gather together a considerablo portion of Nowton's library, which had boen lost to sight for some two hundred years and partly dispersed. Soveral valuable items were recognized from annotations in Nowton's handwriting, which Zoitlinger had studied with much care. It was thus possible, for 
example, to identify Newton's own copy of Barrow's "Euclid", and first and second editions of the "Principia" with his manuscript revisions and additions. The collection was purchased by the Pilgrim Trust and presented to Trinity College, Cambridge, in the library of which it now rests ; but for Zeitlinger's detective skill, scholarly enthusiasm and admiration for Newton, the opportunity of assembling this historic collection might have vanished for ever.

\section{NEWS and VIEWS}

\section{Meteorological Office: Headquarters Reorgan- ization}

'THE present structure of the Meteorological Office was set up in 1957 as a result of the recommendations of the Brabazon Committee. The forthcoming move of the headquarters sections of the Office, now divided between London, Harrow and Dunstable, to Bracknoll during 1961 has provided an opportunity to reconsider that organization in the light of changes which have taken place, and are likely to take place in the future, in meteorology. The division of the Office into two directorates, for services and for research, respectively, with an administrative division controlled by an assistant secretary, will romain unchanged. The balance between the research and services directorates has been improved by the creation of a new deputy director post, which has been filled by Mr. J. S. Sawyer, formerly chief forecasting research officer. $\mathrm{He}$ will be deputy director (dynamical research), in charge of climatological research in addition to dynamical and synoptic research. This reflects the view that forecasting work should be closely integrated with climatological investigations. The importance of the relation between the latter and long-range forecasting, in particular, is emphasized by the transfer of longrange forecasting research from the synoptic research to the climatological research branch.

Two aspects of the work of the directorate of services have increased greatly in importance since 1957. One is the rapid growth of public sorvices, and this is catered for by the creation of an assistant director (general services) post, whose main concern will be agricultural services and tho Weathor Information Contres. The Climatological Services Branch will now be responsible for all climatological inquiries of a routine nature, including world climatology and marine climatology (formorly doalt with by the Climatological Research and Marine Meteorology Branches, respectively). The second development is the increasing complexity of the problems of data processing, and a new post, assistant director (support servicos), has boen croatod to doal with these probloms. The creation of the new branch will facilitate the development of an integrated system of data colloction, processing and storage, a problem which has been the subject of much intensive work in the Office during the past few year's.

Dr. J. M. Stagg, C.B., O.B.E.

ON September 7, Dr. J. M. Stagg rotirod from his position as director of services of the Meteorological Office. Dr. Stagg, who comes from Dalkeith, Midlothian, joined the Meteorological Offico in 1926, and during 1932-33 led the highly successful British Polar Year Expedition to Fort Rae in Canada. His name soon became well known among geophysicists, and in 1939 he was appointed superintendent of Kew Observatory, where he carried out some notable work in radiation. In 1943, Dr. Stagg was made chief meteorological adviser to the Suprome Commander, Allied Forces, Europe, and it was he who briefed General Eisenhower in preparation for the $D$-day landings in Normandy in 1944. For his war-time sorvices Dr. Stagg was made an Officer of the Legion of Merit by tho President of the United States. After the War, Dr. Stagg was made principal deputy director of the Meteorological Office, and in 1957 he was appointed to the newly created post of director of services, responsible for the 'operational' side of the Office. His keen physical insight and oxcellent administrative qualities made him outstandingly successful in this capacity. He was created a C.B. in 1954. In the international field, Dr. Stagg has taken a keen interest in the activities of the Inter. national Union of Geodesy and Geophysics, and he was for a time general secretary of that Union. In 1955, he was awarded the Causs-Weber Medal for his contributions to geomagnetism. It is understood that he intends to resume his work in this field during his retirement.

Dr. A. C. Best, O.B.E.

ON September 8, Dr. A. C. Best succeeded Dr. J. M. Stagg as director of services of the Meteorological Office. After graduating with first-class honours in mathematics and physics at the University College of Wales, Cardiff, Dr. Best joinod tho Meteorological Office in 1926 as a junior professional assistant. During his career he has had a wide experience of both the research side and the operational side of the Office, at home and abroad. His early work was in the field of atmospheric turbulenee, eulminating in the publication of an important Geophysical Mernoir on the transfer of heat and momentum in the lowest layers of the atmosphore. His later research has been devoted mainly to cloud physics, and ho has written a number of papers on the formation and size distribution of raindrops and cloud droplots. Ho was awarded the L. G. Groves Memorial Prize for Meteorology in 1952, and made O.B.E. in 1953. Since 1955) Dr. Best has been a deputy director on the services side of the Meteorological Office.

\section{Zoology in the University of Delhi :}

Prof. B. R. Seshachar

Prof. B. R. Seshachar, who has been professor of zoology in the University of Mysore since 1946, has been appointed professor of zoology in the Univorsity of Delhi. After a fow papers on teleosts, anura and palæontology, he worked during 1932-45 on Gymnophiona, describing new species and investigating their development, their germ colls and their cytology. His discovery of a homologue of Bidder's organ is perhaps not universally known. Since 1946 he has been mainly concerned with ciliate Protozoa. India can probably fill many gaps in our existing knowledge of this group. For examplo, Seshachar has made a 